\title{
ANALISIS KUALITAS PELAYANAN YANG MEMBEDAKAN KEPUASAN DAN KETIDAKPUASAN PELANGGAN TELKOM FLEXI
}

\author{
Mahlia Muis \\ Fakultas Ekonomi Universitas Hasanuddin \\ Jln. Sunu kompleks UNHAS blok LX 14 Makassar
}

\begin{abstract}
This research was conducted based on the fact that service quality plays an important role on determining the difference between satisfaction and dissatisfaction customers. The research findings indicate, using discriminant analysis with force method, it shows that significant difference between satisfaction and dissatisfaction customers in terms of service quality (tangibility, reliability, responsiveness, assurance, and emphaty).
\end{abstract}

Key words: service quality, satisfaction and dissatisfaction customers

Pendapat para pakar manajemen bahwa trend pemasaran internasional pada abad 21 bergeser dari pendekatan transaksional ke pendekatan relasional yang berfokus kepada pemenuhan kebutuhan, kepuasan, dan kesenangan pelanggan. Inti dari pemasaran relasional adalah bagaimana pihak produsen mencari cara untuk mempertahankan pelanggan dalam jangka panjang atas dasar kepercayaan dan kesetiaan pelanggan. Salah satu alasan mengapa perusahaan menerapkan pendekatan relasional, karena persaingan yang semakin kompetitif di era globalisasi ini. Untuk memenangkan persaingan, perusahaan harus mampu memberikan kepuasan kepada pelanggannya, misalnya dengan memberikan produk yang bermutu, harga yang ditawarkan lebih murah, pelayanan yang lebih cepat dan memuaskan sehingga nampak lebih baik dibandingkan pesaing lainnya. Atas dasar itu perusahaan harus melakukan pengukuran tingkat kepuasan pelanggan agar segera diketahui atribut apa dari suatu produk yang bisa menyebabkan pelanggan puas atau tidak puas.

Dari keseluruhan kegiatan yang dilakukan oleh sebuah perusahaan, akan bermuara pada nilai yang akan diberikan oleh pelanggan mengenai 
kepuasan yang dirasakan. Kepuasan merupakan tingkat perasaan dimana seseorang menyatakan hasil perbandingan atas kinerja produk/jasa yang diterima dan yang diharapkan. Dalam era globalisasi ini, perusahaan akan selalu menyadari pentingnya faktor pelanggan. Oleh karena itu mengukur tingkat kepuasan para pelanggan sangatlah perlu, walaupun hal tersebut tidaklah mudah.

Dalam menentukan tingkat kepuasan pelanggan terdapat lima faktor utama yang harus diperhatikan oleh perusahaan, yaitu kualitas produk, kualitas pelayanan, emosional, harga dan biaya.

Tingkat kualitas pelayanan dapat mencapai kepuasan pelanggan dengan beberapa pendekatan (Kotler, 1997) sebagai berikut:

1. Memperkecil kesenjangan-kesenjangan yang terjadi antara pihak manajemen dan pelanggan.

2. Perusahaan harus mampu membangun komitmen bersama untuk menciptakan misi di dalam proses perbaikan pelayanan.

3. Memberi kesempatan kepada pelanggan untuk menyampaikan keluhan dengan membentuk komplain and suggestion system (sistem keluhan dan saran).

4. Mengembangkan dan menerapkan accountable, proactive, partnership marketing sesuai dengan situasi pemasaran.

Jadi salah satu faktor yang menentukan tingkat keberhasilan dan kualitas perusahaan seperti yang disebutkan di atas, adalah kemampuan perusahaan dalam memberikan pelayanan kepada pelanggan. Keberhasilan perusahaan dalam memberikan pelayanan yang bermutu kepada para pelanggannya, pencapaian pangsa pasar yang tinggi, serta peningkatan profil perusahaan tersebut sangat ditentukan oleh pendekatan yang digunakan (Zeithaml, Berry, Parasuraman, 1996). Konsekuensi atas pendekatan kualitas pelayanan suatu produk memiliki esensi penting bagi strategi perusahaan untuk mempertahankan diri dan mencapai kesuksesan dalam menghadapi persaingan.

Salah satu pendekatan kualitas pelayanan yang banyak dijadikan acuan dalam riset pemasaran adalah model SERVQUAL (Service Quality) yang dikemukakan oleh Parasuraman, Zeithaml, dan Berry dalam serangkaian 
penelitian mereka Parasuraman (1988) menyimpulkan terdapat lima dimensi SERVQUAL sebagai berikut:

1. Reliability, atau kehandalan yaitu kemampuan perusahaan untuk memberikan pelayanan sesuai yang dijanjikan secara akurat dan terpercaya. Kinerja harus sesuai dengan harapan pelanggan yang berarti ketepatan waktu, pelayanan yang sama untuk semua pelanggan tanpa kesalahan, sikap yang simpatik dan dengan akurasi yang tinggi.

2. Assurance, atau jaminan dan kepastian, yaitu pengetahuan, kesopansantunan, dan kemampuan para pegawai perusahaan untuk menumbuhkan rasa percaya para pelanggan kepada perusahaan.

3. Tangibles, atau bukti fisik yaitu kemampuan suatu perusahaan dalam menunjukkan eksistensinya kepada pihak eksternal. Penampilan dan kemampuan saran dan prasarana fisik perusahaan dan keadaan lingkungan sekitarnya adalah bukti nyata dari pelayanan yang diberikan oleh pemberi jasa.

4. Emphaty, yaitu memberikan perhatian yang tulus dan bersifat individual atau pribadi yang diberikan kepada pelanggan dengan berupaya memahami keinginan konsumen.

5. Responsiveness, atau ketanggapan yaitu suatu kemauan untuk membantu dan memberikan pelayanan yang cepat (responsif) dan tepat kepada pelanggan dengan menyampaikan informasi yang jelas.

Penelitian ini dilakukan pada PT Telkom sebagai industri jasa telekomunikasi, telah mengembangkan jasa-jasa baru, salah satu produknya adalah Telkom Flexi, yaitu layanan jasa telekomunikasi yang berupa suara dan data berbasis non kabel dengan teknologi CDMA ( Code Division Multiple Acces ). Teknologi CDMA ini menawarkan kualitas suara yang lebih jernih dan komunikasi data yang cepat, harga atau tarif yang lebih murah, investasi yang kecil dan keamanan dalam berkomunikasi. Bagi perusahaan, sangat penting untuk mengetahui kualitas pelayanan yang dapat membedakan kepuasan dan ketidakpuasan pelanggannya agar supaya harapan dan persepsi konsumen dapat disamakan atau bahkan persepsi konsumen dapat melebihi harapannya.

Berdasarkan latar belakang di atas, maka masalah dalam penelitian ini adalah apakah dimensi kualitas pelayanan (tangibility, reliability, responsiveness, 
assurance, dan emphaty) memberikan perbedaan yang signifikan terhadap kepuasan dan ketidakpuasan pelanggan telkom flexi.pada PT Telkom Kandatel Makassar dan manakah diantara dimensi-dimensi kualitas pelayanan yang paling membedakan kepuasan dan ketidakpuasan pelanggan Telkom Flexi pada PT Telkom Kandatel Makassar.

\section{KUALITAS (QUALITY)}

\section{Pengertian Kualitas (Quality)}

Kualitas adalah keseluruhan ciri-ciri, dan karakteristik-karakteristik dari suatu produk/jasa dalam hal kemampuannya untuk memenuhi kebutuhankebutuhan yang telah ditentukan atau yang tersirat. Personalitas kualitas tidak saja menjadi satu-satunya alat untuk memenangkan persaingan, tetapi sudah menjadi persyaratan untuk masuk kedunia bisnis atau untuk dapat tetap survive.

Kualitas tidak hanya diartikan secara sederhana yang berhubungan dengan mutu produk akhir saja, akan tetapi juga terkait arti kualitas pelayanan, sistem dan kualitas pelaksanaan pekerjaan. Hasil dari realisasi penjabarannya, bahwa kualitas sebagai konsekuensi pengembalian biaya yang telah dikeluarkan untuk suatu produk atau jasa, merupakan sumbangan yang besar artinya dalam berhasilnya suatu usaha. Konsep kualitas itu sendiri pada dasarnya bersifat relatif, yaitu tergantung dari perspektif yang digunakan untuk menentukan ciri-ciri dan spesifikasi.

Pada dasarnya terdapat 3 (tiga) orientasi kualitas yang seharusnya konsisten satu sama lain yaitu persepsi konsumen, produk/jasa dan proses. Untuk yang berbentuk barang ke tiga orientasi ini dapat dibedakan dengan jelas. Untuk jasa, produk dan proses mungkin tidak dapat dibedakan dengan jelas, bahkan produknya adalah proses itu sendiri.

Kualitas memiliki hubungan yang erat dengan kepuasan pelanggan. Kualitas memberikan suatu dorongan kepada pelanggan untuk menjalin ikatan hubungan yang kuat dengan perusahaan. Dalam jangka panjang ikatan seperti ini memungkinkan perusahaan untuk memahami dengan seksama harapan pelanggan serta kebutuhan mereka. Dengan demikian perusahaan dapat meningkatkan kepuasan pelanggan di mana perusahaan memaksimumkan 
pengalaman pelanggan yang kurang menyenangkan. Pada gilirannya kepuasan pelanggan dapat menciptakan kesetiaan atau loyalitas pelanggan kepada perusahaan yang memberikan kualitas memuaskan.

Selain itu perusahan juga dapat meningkatkan pangsa pasarnya melalui pemenuhan kualitas yang bersifat customer-driven. Hal ini akan memberikan keunggulan harga dan customer value. Customer Value merupakan kombinasi dari manfaat dan pengorbanan yang terjadi apabila pelanggan menggunakan suatu barang dan jasa guna memenuhi kebutuhan tertentu (Bounds, 1994). Bila kualitas yang dihasilkan superior dan pangsa pasar yang dimiliki besar, maka profitabilitasnya terjamin. Jadi, kualitas dan profitabilitas berkaitan erat. Perusahaan yang menawarkan barang atau jasa berkualitas superior pasti dapat mengalahkan pesaingnya yang menghasilkan kualitas inferior.

\section{Kualitas Jasa}

Kualitas jasa adalah tingkat keunggulan yang diharapkan dan pengendalian atas tingkat keunggulan tersebut untuk memenuhi keinginan pelanggan. Jadi ada dua faktor utama yang mempengaruhi kualitas jasa, yaitu expected service dan perceived service (Parasuraman 1985). Apabila jasa yang diterima atau dirasakan (perceived service) sesuai dengan yang diharapkan, maka kualitas jasa dipersepsikan baik dan memuaskan. Jika jasa yang diterima melampaui harapan pelanggan, maka kualitas jasa dipersepsikan sebagai kualitas yang ideal. Sebaliknya jika jasa yang diterima lebih rendah dari pada yang diharapkan, maka kualitas jasa dipersepsikan buruk. Dengan demikian baik tidaknya kualitas jasa tergantung pada kemampuan penyedia jasa dalam memenuhi harapan pelanggannya secara konsisten.

Kualitas harus dimulai dari kebutuhan pelanggan dan berakhir pada persepsi pelanggan. (Kotler, 1994). Hal ini berarti bahwa kualitas yang baik bukanlah berdasarkan sudut pandang atau persepsi pihak penyedia jasa, melainkan berdasarkan sudut pandang atau persepsi pelanggan.

\section{Dimensi Kualitas Jasa}

Terdapat 5 (lima) dimensi yang digunakan untuk menentukankualitas jasa, yaitu:

a. Tangibles (bukti fisik)

b. Reliability (keandalan) 

c. Responsiveness (ketanggapan)
d. Assurance (jaminan)
e. Empathy

\section{Model Kualitas Jasa}

Parasuraman, Zeithaln dan L. Berry (1985), melakukan penelitian mengenai customer perceived quality pada empat industri jasa, yaitu Retail banking, Credit Card, Securities brokerage dan Produk repair and maintenance. Dalam penelitian tersebut, mereka mengidentifikasi 5 group yang menyebabkan kegagalan penyampaian jasa (lihat gambar 1). Kelima gap tersebut adalah :

a. Gap antara harapan konsumen dan persepsi manajemen (gap 1). Pada kenyataannya pihak manajemen suatu perusahaan tidak selalu dapat merasakan atau memahami apa yang diinginkan para pelanggan secara tepat. Akibatnya manajemen tidak mampu mengetahui bagaimana suatu jasa seharusnya di desain, dan jasa-jasa pendukung apa saja yang diinginkan konsumen.

b. Gap antara persepsi manajemen terhadap harapan konsumen dan spesifikasi kualitas jasa (gap 2).

Kadangkala manajemen mampu memahami secara tepat apa yang diinginkan oleh pelanggan, tetapi mereka tidak menyusun suatu standar kinerja tertentu yang jelas. Hal ini bisa dikarenakan tiga faktor, yaitu tidak adanya komitmen total manajemen terhadap kualitas jasa, kekurangan sumber daya, atau karena adanya kelebihan permintaan.

c. Gap antara spesifikasi kualitas jasa dan penyampaian jasa (Gap 3).

Ada beberapa penyebab terjadinya gap ini, misalnya karyawan kurang terlatih, beban kerja melampaui batas, tidak dapat memenuhi standar kinerja yang ditetapkan, atau tidak mau memenuhi standar kinerja yang ditetapkan. Selain itu mungkin pula karyawan dihadapkan pada standarstandar yang kadangkala saling bertentangan satu sama lain.

d. Gap antara penyampaian jasa dan komunikasi eksternal (gap 4). Seringkali harapan pelanggan dipengaruhi oleh iklan dan pernyataan janji di buat oleh perusahaan. Resiko yang dihadapi perusahaan adalah apabila janji 
yang diberikan ternyata tidak dapat dipenuhi. Maka komunikasi eksternal yang dilakukan perusahaan tersebut telah mendistorsi harapan konsumen dan menyebabkan terjadinya persepsi negatif terhadap kualitas jasa perusahaan tersebut.

e. Gap antara jasa yang dirasakan dan jasa yang diharapkan (gap 5). Hal ini terjadi apabila pelanggan mengukur kinerja/prestasi perusahaan dengan cara yang berlainan, atau bisa juga keliru mempersepsikan kualitas jasa tersebut.

Gambar 1

Model Kualitas Jasa (Gap Model)

\section{KONSUMEN}

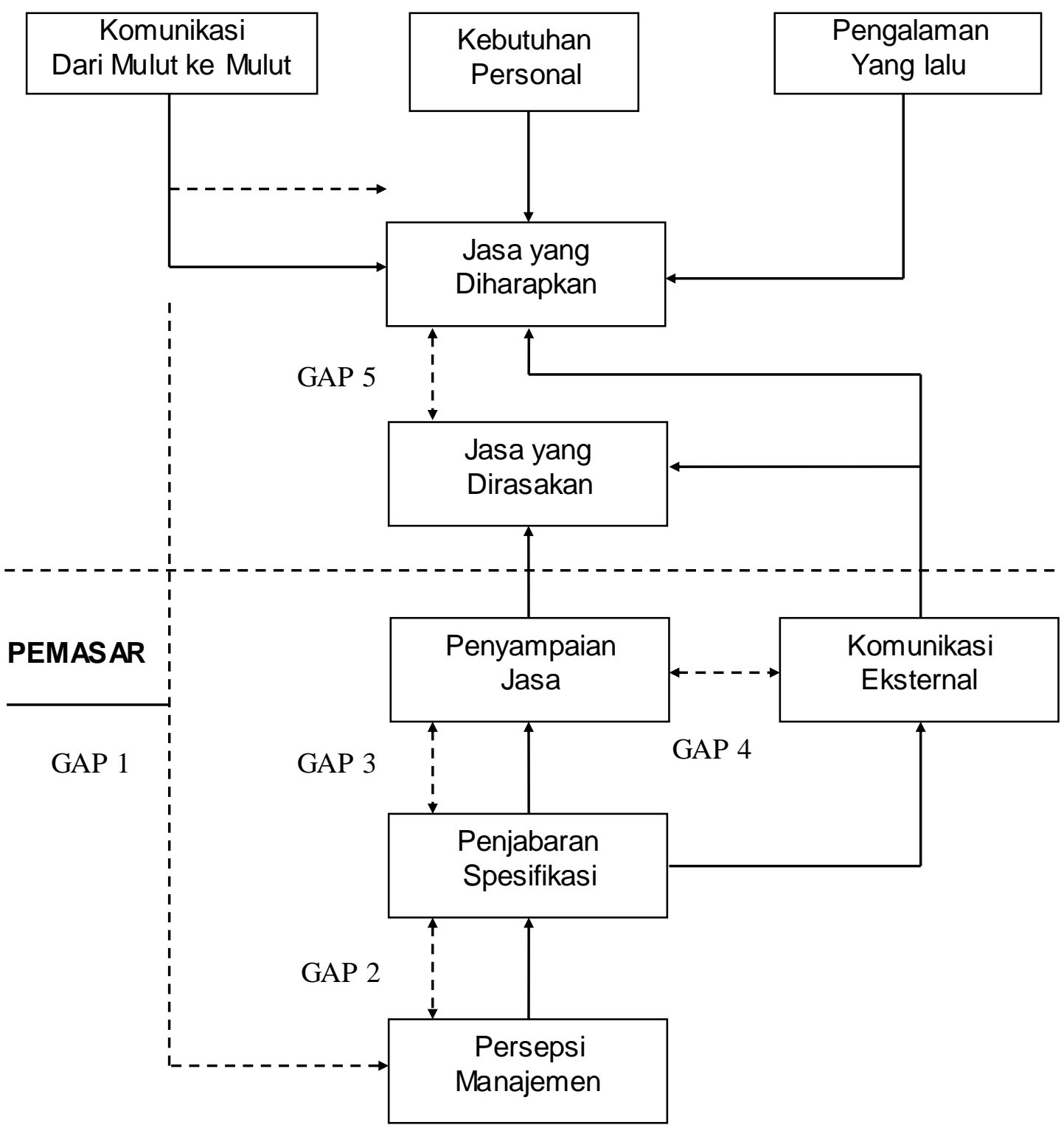


Sumber: Parasuraman, A., (1985), “ A Conceptual Model of Service Quality and Its Implications for Future Research", Journal of marketing, Vol. 49 (afll), p.44.

\section{Hipotesis}

1. Diduga variabel-variabel dalam kualitas pelayanan (tangible, realibilitu, responsivenes, assurance dan emphaty) secara simultan memberikan perbecinm. yang signifikan terhadap kepuasan dan ketidakpuasan Pelanggan Telkom Flexi.

2. Diduga variabel reliability merupakan variabel yang paling dominan membedakan kepuasan dan ketidakpuasan Pelanggan Telkom Flexi.

\section{METODE}

\section{Metode Analisis}

Analisis discriminant digunakan untuk menentukan faktor-faktor apa yang menjelaskan perbedaan antara kepuasan dan ketidakpuasaan pelanggan Telkom Flexi. Variabel independen adalah kualitas layanan yang terdiri dari tangibility, responsiveness, reliability, assurance dan emphaty. Model analisis diskriminannya adalah :

$Y=b_{1} x_{1}+b_{2} x_{2}+b_{3} x_{3}+b_{4} x_{4}+b_{5} x_{5}$

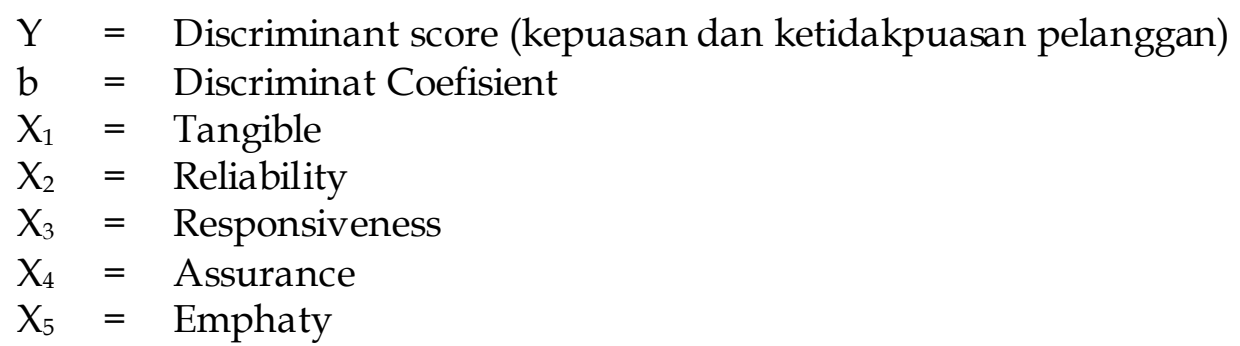

Identifikasi Variabel Penelitian

Tabel. 1

Variabel Dimensi Kualitas Pelayanan

\begin{tabular}{|c|c|cl|}
\hline VARIABEL & DIMENSI & \multicolumn{1}{|c|}{ INDIKATOR } \\
\hline Kualitas Layanan & $\begin{array}{l}\text { Kehandalan } \\
\text { (Reliability) }\end{array}$ & $1) \begin{array}{l}\text { Aktivasi/Pasang baru TelkomFlexi cepat } \\
\text { dan handal }\end{array}$
\end{tabular}




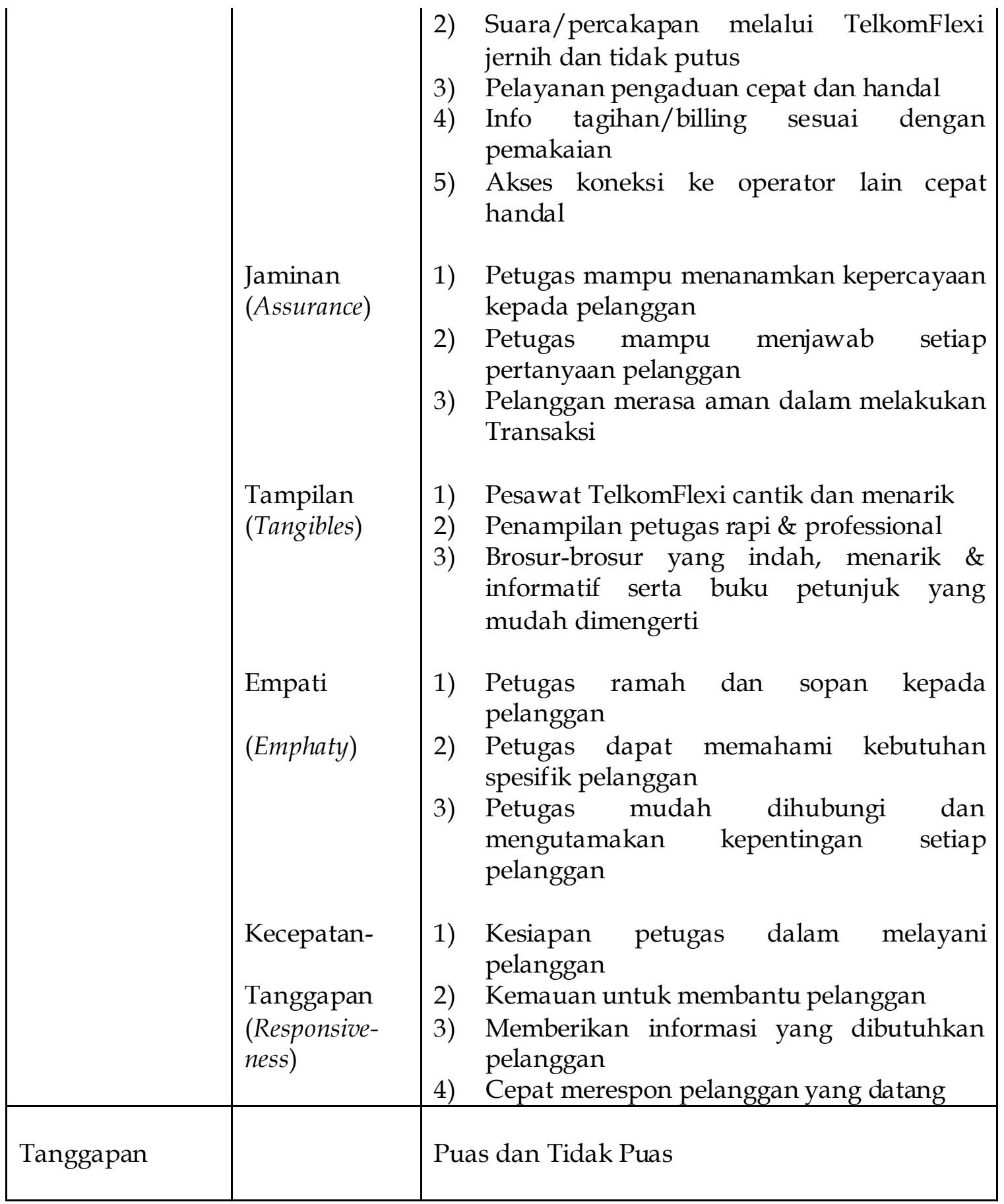

\section{Populasi dan Sampel Penelitian}

Oleh karena dalam penelitian ini sangat sulit mendapatkan responden keseluruhan, karena terdiri dari pelanggan prabayar dan pascabayar, maka jumlah sampel pada penelitian ini ditentukan sebesar 100 responden. Penentuan besarnya sample sebanyak 100 disebabkan karena adanya keterbatasan waktu dari peneliti. 
Pengambilan sampel juga mengikuti metode one-sample dependent, yaitu pengambilan sampel tanpa membedakan kelompok responden dalam hal ini tidak dibedakan antara pelanggan Flexi Trendy untuk pra bayar dan Flexi Classy untuk pasca bayar (Malhotra, 1999; Supranto, 1997)).

\section{Definisi Operasional}

Tingkat kepuasan dan ketidakpuasan pelanggan adalah penilaian pelanggan terhadap selisih antara apa yang diterima (perceived) pelanggan dengan harapannya (expected). Pada Dimensi responsiveness, assurance, realibility, empathy, tangibles, yang diukur dengan menggunakan lima tingkatan Skala Likert.

1. Tangibility adalah penilaian pelanggan terhadap penampilan atau kemampuan sarana dan prasarana fisik perusahaan dan keadaan lingkungan sekitarnya, yang meliputi fasilitas fisik, perlengkapan dan peralatan yang digunakan (teknologi) serta penampilan pegawainya.

2. Responsiveness adalah penilaian pelanggan terhadap petugas pelayanan Service Point membantu memberikan pelayanan yang cepat (responsive) dan tepat kepada pelanggan, dengan menyampaikan informasi yang jelas.

3. Reliability yaitu penilaian pelanggan terhadap kemampuan perusahaan untuk memberikan pelayanan sesuai yang dijanjikan secara akurat dan terpercaya. Kinerja harus sesuai dengan harapan pelanggan yang berarti ketepatan waktu, pelayanan yang sama untuk semua pelanggan tanpa kesalahan, sikap yang simpatik, dan dengan akurasi yang tinggi.

4. Assurance yaitu penilaian pelanggan terhadap keahlian dan pengetahuan, kesopansantunan, dan kemampuan para pegawai perusahaan untuk menumbuhkan rasa percaya para pelanggan kepada perusahaan, terdiri dari beberapa komponen antara lain : komunikasi, kredibilitas, keamanan, kompetensi dan sopan santun.

5. Emphaty yaitu memberikan perhatian yang tulus dan bersifat individual atau pribadi yang diberikan kepada para pelanggan dengan berupaya memahami keinginan konsumen.

\section{HASIL DAN PEMBAHASAN}




\section{Pengujian Hipotesis}

\section{Pengujian Signifikansi Variabel Diskriminan}

Untuk mengetahui apakah kelima variabel dari SERVQUAL, yaitu reliability, assurance, tangible, emphaty, dan responsiveness secara simultan dapat membedakan konsumen yang puas dan tidak puas terhadap produk telkom flexi, maka dilakukan uji signifikansi variabel diskriminan dengan force method. Ringkasan hasil uji tersebut dapat diilustrasikan pada tabel di bawah ini:

Tabel 2

\section{Ringkasan Hasil Uji Diskriminan kedua kelompok konsumen yang puas dan} tidak puas

Tests of Equality of Group Means

\begin{tabular}{|l|r|r|r|r|r|}
\hline & \multicolumn{1}{|c|}{$\begin{array}{c}\text { Wilks' } \\
\text { Lambda }\end{array}$} & \multicolumn{1}{|c|}{$\mathrm{F}$} & $\mathrm{df1}$ & \multicolumn{1}{c|}{$\mathrm{df2}$} & \multicolumn{1}{c|}{ Sig. } \\
\hline Reliabilitas &, 392 & 151,737 & 1 & 98 &, 000 \\
Assurance &, 523 & 89,454 & 1 & 98 &, 000 \\
Tangible &, 620 & 60,122 & 1 & 98 &, 000 \\
Emphaty &, 633 & 56,859 & 1 & 98 &, 000 \\
Responsiveness &, 613 & 61,968 & 1 & 98 &, 000 \\
\hline
\end{tabular}

\section{Uji Signifikansi Model}

Untuk mengetahui kontribusi masing-masing variabel dalam dilakukan dengan uji statistik Wilk's Lamda terhadap variabel pembeda. Hasil uji statistik Wilk's Lamda ditunjukkan dalam tabel di atas.

Berdasarkan hasil uji univariate bagi variabel-variabel diskriminan secara parsial dengan statistik F-ratio, diketahui ada 5 variabel yang signifikan membedakan kepuasan dan ketidakpuasan konsumen karena tingkat signifikannya di bawah 0,05. Variabel-variabel tersebut adalah Reliability, Assurance, Tangible, Emphaty, dan Responsiveness.

Karena hasil uji ini menunjukkan sebagian besar variabel dapat membedakan tingkat kepuasan dan ketidakpuasan konsumen, dengan demikian dapat dikatakan bahwa variabel-variabel SERVQUAL secara signifikan dapat membedakan konsumen yang puas dan tidak puas dengan pelayanan telkomflexi. Berdasarkan uji ini, maka hipotesis penelitian diterima yaitu bahwa variabel-variabel reliability, assurance, tangible, emphaty dan responsiveness secara simultan dapat membedakan tingkat kepuasan konsumen. Dengan kata lain 
bahwa H0 ditolak dan H1 diterima. Kelima variabel SERVQUAL dapat digunakan untuk membentuk variabel diskriminan.

\section{Uji Keeratan Hubungan}

Hubungan antara variabel pembeda (discriminator variables) dengan variabel terikat (discriminant value atau $z$ score) serta sampai seberapa besar variabel terikat dapat dijelaskan oleh variabel pembeda dapat dilihat dari angka canonical correlation. Dari hasil perhitungan diperoleh nilai canonical correlation sebesar 0,899 atau 89,90\% . Ini berarti bahwa keseluruhan variabel SERVQUAL secara bersama-sama memiliki hubungan yang erat dengan variabel terikat. Artinya, sumbangan variabel SERVQUAL untuk mengidentifikasi perbedaan tingkat kepuasan konsumen telkomflexi sebesar 89,90\% dapat dijelaskan oleh variabel pembeda (discriminant variable), sedangkan sisanya dijelaskan oleh variabel lain di luar model yang tidak dimasukkan dalam analisis ini.

a. Kriteria Klasifikasi Observasi

Kriteria klasifikasi observasi ke dalam kelompok konsumen yang puas dan tidak puas perlu dibuktikan ketepatannya. Metode yang dapat digunakan untuk menilai ketepatan ini adalah metode cut-off value yang diperoleh dari fungsi centroid group.

b. Hasil Klasifikasi

Berdasarkan cut-off value, maka klasifikasi observasi ke dalam kelompok konsumen yang puas dan tidak puas diringkas dalam tabel di bawah ini:

Tabel 3

Hasil Klasifikasi Dua Kelompok responden

\begin{tabular}{|l|c|c|c|}
\hline \multirow{2}{*}{$\begin{array}{c}\text { Kelompok } \\
\text { responden }\end{array}$} & \multirow{2}{*}{$\begin{array}{c}\text { Jumlah } \\
\text { Observasi }\end{array}$} & \multicolumn{2}{|c|}{ Prediksi Keanggotaan Kelompok } \\
\cline { 3 - 4 } & 50 & $50(100 \%)$ & $0(0 \%)$ \\
\hline Puas & 50 & $3(6 \%)$ & $47(94 \%)$ \\
\hline Tidak Puas & & \multicolumn{2}{|c|}{} \\
\hline
\end{tabular}

Tabel di atas menunjukkan bahwa kelompok responden yang puas (50 observasi), diklasifikasikan secara benar sebesar 100\% (50 observasi) jadi tidak terjadi kesalahan klasifikasi. Sedangkan kelompok responden yang tidak puas (50 observasi) diklasifikasikan secara benar sebesar 94\% (47 observasi) atau terjadi kesalahan klasifikasi sebesar 6\% (3 observasi) yaitu responden nomor 1, 2 dan 36. 
Untuk membuktikan keakuratan pengklasifikasian antara observasi yang puas dan tidak puas, maka diadakan perbandingan antara change model (C pro dan $C$ max) dengan hit ratio. Berdasarkan data hasil pengklasifikasian pada tabel di atas diperoleh:

$$
\begin{aligned}
& \begin{aligned}
C \text { pro } & =p^{2}+(1-p)^{2}=(50 / 100)^{2}+(1-50 / 100)^{2} \\
& =0,50=50 \%
\end{aligned} \\
& \begin{aligned}
C \max & =(50 / 100) \times 100 \%=50 \%
\end{aligned} \\
& \text { Hit Ratio }=(50+47) / 100 \times 100 \%=97 \%
\end{aligned}
$$

Perhitungan di atas menunjukkan bahwa hit ratio > C pro yaitu 97\% lebih besar dari 50\%, maka dapat disimpulkan bahwa tingkat keakuratan pengklasifikasian tinggi. Artinya variabel-variabel SERVQUAL dapat mengelompokkan secara tepat sebesar $97 \%$ dan tingkat kesalahannya hanya sebesar 3\%.

\section{Identifikasi Variabel Dominan: Stepwise Method (Hipotesis 2)}

Untuk mengidentifikasi variabel-variabel SERVQUAL mana yang paling signifikan membedakan tingkat kepuasan konsumen dilakukan analisis dengan metode stepwise.

Berdasarkan uji stepwise, kelima variabel SERVQUAL merupakan variabel- variabel yang dominan sebagai pembeda antara kepuasan dan ketidakpuasan konsumen. Ringkasan uji diskriminan dengan metode stepwise diilustrasikan pada tabel di bawah ini.

Tabel 4

Ringkasan Uji Diskriminan atas variabel-variabel Pembeda kepuasan dan ketidakpuasan konsumen.

\begin{tabular}{|l|r|r|r|r|r|}
\hline \multicolumn{1}{|c|}{ Variabel } & $\begin{array}{c}\text { Wilk's } \\
\text { Lambda }\end{array}$ & F-Ratio & Significance & $\begin{array}{c}\text { Koef.Disc. } \\
\text { Kanonik }\end{array}$ & $\begin{array}{c}\text { Fungsi } \\
\text { Mat-riks } \\
\text { Struktur }\end{array}$ \\
\hline Reliability & 0,392 & 151,737 & 0,000 &, 732 & 0,607 \\
\hline Assurance & 0,523 & 131,652 & 0,000 & 0,367 & 0,466 \\
\hline Responsiveness & 0,613 & 109,110 & 0,000 & 0,331 & 0,388 \\
\hline Tangible & 0,620 & 91,865 & 0,000 & 0,387 & 0,382 \\
\hline Emphathy & 0,633 & 79,036 & 0,000 & 0,291 & 0,371 \\
\hline
\end{tabular}

Berdasarkan Tabel di atas, terdapat lima variabel pembeda yang dominan membedakan tingkat kepuasan dan ketidakpuasan konsumen, yaitu Reliability, Assurance, Responsiveness, Tangible, dan Emphaty. Kelima variabel tersebut mempunyai tingkat signifikansi yang sangat tinggi $(0,000<0,05)$, hal ini 
membuktikan bahwa kelima variabel tersebut dapat membedakan dengan jelas tingkat kepuasan dan ketidakpuasan konsumen.

Untuk mengetahui variabel yang menjadi kontributor terbesar diantara ketiga variabel tersebut, dapat dilihat dari nilai fungsi struktur matriks yang tertinggi. Berdasarkan Tabel di atas, variabel Reliability memiliki nilai fungsi struktur matriks yang tertinggi yaitu sebesar 0,607, sehingga dapat disimpulkan bahwa variabel ini merupakan kontributor yang paling besar membedakan tingkat kepuasan dan ketidakpuasan konsumen.

Fungsi diskriminan ternyata sangat signifikan yaitu 0,899 atau 89,90\%, maka dapat disimpulkan bahwa 89,90\% variasi variabel dependen $Y$ yang dapat dijelaskan oleh kelima variabel independen SERVQUAL (reliability, assurance, tangible, emphaty dan responsiveness).

Berdasarkan temuan tersebut di atas, maka hipotesis kedua yang menyatakan bahwa variabel reliability yang merupakan variabel yang signifikan menjadi pembeda kedua kelompok konsumen yang puas dan tidak puas dengan pelayanan Telkomflexi diterima. Dengan kata lain, H0 ditolak dan H1 diterima.

Hasil penelitian ini memang mendukung fenomena yang terjadi di lapangan, bahwa memang variabel Reliability sering terjadi keluhan konsumen dengan adanya kenyataan bahwa suara percakapan TelkomFlexi sering terganggu dan sering putus, akses koneksi ke operator lain kadang-kadang terganggu, dan Telkom lambat dalam mengatasi pengaduan.

\section{KESIMPULAN DAN SARAN}

\section{Kesimpulan}

1. Berdasarkan uji diskriminan dengan menggunakan force method disimpulkan bahwa secara simultan variabel reliability, assurance, tangible, emphaty, dan responsiveness dalam SERVQUAL dapat membedakan tingkat kepuasan dan ketidakpuasan konsumen TelkomFlexi di Makassar

2. Berdasarkan uji diskriminan dengan menggunakan metode stepwise disimpulkan bahwa variabel yang paling dominan memjadi pembeda kepuasan dan ketidakpuasan pelanggan Telkomflexi adalah variabel reliability. 


\section{Saran}

1. Mempertahankan standar pelayanan terhadap konsumen dengan memperhatikan kelima variabel SERVQUAL yaitu reliability, assurance, tangible, emphaty, dan responsiveness, karena berdasarkan penelitian ini variabel-variabel tersebut signifikan membedakan tingkat kepuasan dan ketidakpuasan konsumen Telkomflexi dengan tingkat signifikansi yang sangat tinggi.

2. PT Telkom Kandatel Makassar sebaiknya lebih memprioritaskan aspek reliability terhadap jasa pelayanan yang ditawarkan, yang meliputi kehandalan dalam aktivasi pasang baru, suara percakapan melalui TelkomFlexi jernih dan tidak putus, pengaduan cepat dan handal, info tagihan sesuai dengan pemakaian, serta yang terpenting pula adalah koneksi ke operator lain cepat. Karena terbukti variabel ini yang paling signifikan membedakan tingkat kepuasan pelanggan.

3. Penelitian selanjutnya disarankan untuk menambah variabel lain selain variabel-variabel SERVQUAL yang menentukan tingkat kepuasan pelanggan diantaranya adalah kualitas produk, emosional pelanggan, harga produk dan biaya. Keempat faktor tersebut bersama-sama dengan kualitas pelayanan adalah faktor-faktor yang membentuk tingkat kepuasan pelanggan.

\section{DAFTAR PUSTAKA}

Hooger, Marthin, 2005. The Customer Expectation and Behavior in Service. http://www.marketing\&behavior.com.

Jargorn, Grahams, 2006. Penetapan Harga Penawaran Jasa dan Produk. httg://www.marketing\&behavior.com.

Kotler, Philip. 1997. Manajemen Pemasaran, Analisis, Perencanaan Implementasi dan Kontrol. Jakarta: Prenhallindo.

Kathryn T, Theus, 2002. Psychology of Customer Behavior. Journal of Marketing. USA.

Machall, Fransturist. 2006. Quality of Product and Service in Marketing of Service. http:1/www.marketing\&behavior.com.

Mowen, John C., dan Minor, Michael. 2001. Customer Behavior Concept. New York: McGraw-Hill. 
Parasuraman, A. Valerie. 2001. Delivering Quality Service. New York: The Free Press.

Rangkuti, Freddy. 2003. Konsep Pengukuran Kepuasan Pelanggan. Jakarta: Penerbit PT, Gramedia Pustaka Utama.

Sekaran, Uma. 2000. Research Methods For Business : A Skill - Buildig Approach. Jakarta: John Quality Control.

Supriyoadi, Rambat. 2001. Manajemen Pemasaran Jasa, Teori dan Praktek. Jakarta: Penerbit Salemba Empat.

Supranto. Johannes. 1997. Pengukuran Tingkat Kepuasan Pelanggan untuk Menaikkan Pangsa Pasar. Jakarta: Rhineka Cipta.

MC. Clove, James. T. And Benson, George, P. 1985. Statistics For Business And Economic. San Fransisco: Dallen Publisheng Company.

Malhotra, Maresh. K. 1999. Marketing Research: An Applied Orientation. New Jersey: Prentice hall, inc.

Zeithaml, Bitner. 2002. The Concept of Customer Satisfaction. USA: The McGrawHill Companies. Inc. 